\title{
Artificial biofilm thickness and salivary flow effects on fluoride efficacy - A model development study
}

\author{
Frank Lippert $^{1 *}$, Anderson T Hara ${ }^{1}$, David Churchley ${ }^{2}$ and Richard JM Lynch ${ }^{2}$ \\ ${ }^{1}$ Indiana University School of Dentistry, Indianapolis, USA \\ ${ }^{2}$ GlaxoSmithKline Consumer Healthcare, Weybridge, UK
}

\begin{abstract}
This laboratory model development study investigated the interaction between artificial biofilm thickness and salivary flow rate on fluoride-mediated prevention of enamel caries lesion formation. This 5-day $\mathrm{pH}$ cycling study on sound bovine enamel specimens utilized a continuous flow model and followed a 4 (agarose biofilm thickness-'no biofilm' $/ 1 / 2 / 3 \mathrm{~mm}) \times 2$ (remineralizing solution flow rate- $0.05 / 0.5 \mathrm{ml} / \mathrm{min}) \times 2$ (fluoride- $0 / 383 \mathrm{ppm}$ as sodium fluoride) factorial design. Vickers surface microhardness change was the outcome measure. Data were analyzed with three-way ANOVA. The three-way interaction gel thickness $\times$ flow rate $\times$ fluoride concentration was significant $(\mathrm{p}=0.0006) .383 \mathrm{ppm}$ fluoride caused less softening than $0 \mathrm{ppm}$ regardless of gel thickness or flow rate. $0.5 \mathrm{ml} / \mathrm{min}$ flow rate caused less softening than $0.05 \mathrm{ml} / \mathrm{min}$ for 'no biofilm' and $1 \mathrm{~mm}$ biofilm thickness regardless of fluoride concentration, for 2 and $3 \mathrm{~mm}$ with $0 \mathrm{ppm}$ F but not for $383 \mathrm{ppm}$ F. For $0.05 \mathrm{ml} / \mathrm{min}$, softening was reduced as gel thickness increased from 'no biofilm'-1-2 mm, but not from $2-3 \mathrm{~mm}$. For $0.5 \mathrm{ml} / \mathrm{min}$, 'no biofilm' caused more softening than 1,2 , and $3 \mathrm{~mm}$, but 1,2 , and $3 \mathrm{~mm}$ were not different from each other for both 0 and $383 \mathrm{ppm}$ F. The present findings suggest that the efficacy of fluoride in preventing enamel demineralization is affected by both biofilm thickness and salivary flow rate, with both thicker biofilms and higher flow rate resulting in less demineralization.
\end{abstract}

\section{Introduction}

Modelling in vivo caries in vitro allows for greater control over experimental variables [1,2]. Although caries is a biofilm-dependent and -mediated disease, the majority of laboratory models employ solutions of organic acids as surrogates for cariogenic bacterial end products. This has the advantage of allowing better control of lesions' severity and mineral distribution, both of which impact on the efficacy of interventions [3]. Fluoride has long been established as an effective, topical intervention to combat caries through enhancement of remineralization of early caries lesions and consequently also lowering their subsequent acid susceptibility due to fluoride incorporation [4]. However, for fluoride to exert its cariostatic properties, it needs to diffuse through the biofilm to reach the enamel surface with the thickness of the biofilm being a rate-limiting parameter [5]. While biofilms have been successfully incorporated into laboratory models by various investigators $[6-8]^{1}$, studying the effect of thickness remains a challenge. Apart from certain devices used in situ that enable the growth of a biofilm to a confined thickness [9], under laboratory conditions, the biofilm is typically allowed to grow without controlling its thickness, although constant depth film fermenters can partially overcome this aspect [10]. A potential solution was offered initially by Lecomte and Dawes [11], later adapted by Blake-Haskins, et al. [12], who introduced the concept of 'artificial biofilms' by utilizing an agarose gel as a surrogate for dental biofilms. The importance of calcium for enhanced fluoride retention was demonstrated [12] which is in agreement with later in vivo studies on human biofilms [13] and on the role of calcium fluoride in caries prevention in general [14], thereby highlighting the potential value of this experimental approach.

Among the numerous risk factors involved in the manifestation and progression of caries [15], salivary flow, has thus far only been insufficiently modelled in vitro, apart from pioneer research in the 1960s [16]. Recent studies concerned with dental erosion/abrasion [17$19]^{2}$, however, showed promise to study salivary flow rate effects also on caries lesion development. Consequently, the aim was to adapt this model to study the effects of artificial biofilm thickness and artificial salivary flow rate on the ability of fluoride to prevent enamel caries lesion formation under continuous flow conditions.

\section{Materials and methods}

\section{Study design}

Sound bovine enamel specimens were allocated to one of 16 experimental groups based on their Vickers surface microhardness. The experimental groups followed a 4 (biofilm thickness; 'no biofilm'/1/2/3 $\mathrm{mm}$; prepared using $1 \% \mathrm{w} / \mathrm{v}$ agarose) $\times 2$ (salivary flow rate; $0.05 / 0.5$ $\mathrm{ml} / \mathrm{min}) \times 2$ (fluoride concentration; $0 / 383 \mathrm{ppm}$ as sodium fluoride) factorial design. Artificial caries lesions were induced in the specimens during a 5- $\mathrm{d} \mathrm{pH}$ cycling period utilizing a continuous flow model and the extent of surface softening characterized using Vickers surface microhardness.

\section{Specimen preparation}

Enamel specimens $\left(4 \times 4 \times 2 \mathrm{~mm}^{3}\right)$ were cut from bovine incisors and embedded in acrylic resin (Varidur, Buehler, Illinois, USA). The

Correspondence to: Frank Lippert, Department of Cariology, Operative Dentistry and Dental Public Health Oral Health Research Institute, Indiana University School of Dentistry 415 Lansing Street, Indianapolis, IN 46202, USA, Tel. +1 317274 3983; Fax +1 317274 5425, E-mail: flippert@iu.edu

Key words: chemical models, dental caries, topical fluorides, xerostomia

Received: October 19, 2017; Accepted: October 24, 2017; Published: October 26, 2017 
resulting blocks were ground flat and polished with water-cooled abrasive disks (500-, 1,200-, 2,400- and 4,000-grit SiC papers; MDFuga, Struers Inc., Ohio, USA) and polishing cloth with diamond suspension ( $1 \mu \mathrm{m}$; Struers Inc., Missouri, USA).

\section{Surface microhardness}

The average Vickers surface microhardness of each sound enamel specimen $\left(\mathrm{VHN}_{\text {sound }}\right)$ was determined from four indentations using a $200 \mathrm{~g}$ load, $15 \mathrm{~s}$ dwelling time and placed approx. $100 \mu \mathrm{m}$ apart in the center of the specimen surface $(2100 \mathrm{HT}$; Wilson Instruments, Massachusetts, USA). Specimens ( $\mathrm{n}=8$ per group) were assigned to the 16 treatment groups based on $\mathrm{VHN}_{\text {sound }}$. After $\mathrm{pH}$ cycling, another four indentations were placed $200 \mu \mathrm{m}$ to the right of the baseline indentations, yielding $\mathrm{VHN}_{\text {post }}$. The change in VHN was calculated: $\Delta \mathrm{VHN}=\mathrm{VHN}_{\text {post }}-\mathrm{VHN}_{\text {sound }}$.

\section{Artificial biofilm}

Artificial biofilm was based on that by Blake-Haskins, et al. [11] an acrylic ring (outer diameter $10 \mathrm{~mm}$, inner diameter $7 \mathrm{~mm}$ ), varying in height (1,2 or $3 \mathrm{~mm}$ ), was glued onto the specimen surface using super glue. A $1 \%$ agarose (Sigma-Aldrich A9539, St. Louis, Missouri, USA) gel was prepared by heating deionized water and agarose under constant stirring. Once the agarose had dissolved (approx. $90^{\circ} \mathrm{C}$ ), the solution was cooled down to approx. $55-60^{\circ} \mathrm{C}$. Then, this solution was pipetted into each acrylic ring until the solution was level with the surface of the ring. The number of droplets was counted for each ring height to ensure comparable gel thicknesses between and within groups.

\section{Solutions}

A pH 5.0 demineralization solution was used: $50.0 \mathrm{mM}$ acetic acid; $2.2 \mathrm{mM} \mathrm{CaCl}_{2} ; 2.2 \mathrm{mM} \mathrm{KH}_{2} \mathrm{PO}_{4} ; 130.0 \mathrm{mM} \mathrm{KCl}$ (all Sigma-Aldrich, St. Louis, Missouri, USA); 0.2\% w/v Carbopol 907 (BF Goodrich Co., Ohio, USA). The remineralizing solution ( $\mathrm{pH} 7.0$ ) had the following composition: $1.5 \mathrm{mM} \mathrm{CaCl}_{2} ; 0.9 \mathrm{mM} \mathrm{KH}_{2} \mathrm{PO}_{4} ; 130.0 \mathrm{mM} \mathrm{KCl} ; 20.0$ mM HEPES (all Sigma-Aldrich, St. Louis, Missouri, USA). Treatment solutions were either deionized water or $383 \mathrm{ppm}$ fluoride as $\mathrm{NaF}$ (Sigma-Aldrich, St. Louis, Missouri, USA), simulating an 1150 ppm fluoride dentifrice after 1:3 dilution during toothbrushing.

\section{Continuous flow model}

The daily $\mathrm{pH}$ cycling regimen is shown in Table 1. A continuous flow model [17-19] was adapted to induce the formation of caries rather than erosive lesions. A schematic drawing of the utilized continuous flow chamber is shown in Figure 1. In short, specimens were individually placed in custom made acrylic devices (four specimens/ device), having their enamel surface or artificial biofilm facing a closed chamber of $41.3 \mu \mathrm{l}$ capacity. Each chamber was connected to one inlet and one outlet fluid tube. The inlet tube was connected to a multichannel peristaltic pump (Masterflex LS, Cole-Parmer, Vernon Hills, Illinois USA) through a two-way tubing system, which included a second tube to allow the remineralizing solution to be injected in conjunction with a demineralization challenge and the two solutions being mixed prior to reaching the specimen. During the last 30 of each $60 \mathrm{~min}$ of demineralization, the demineralizing solution was mixed with the remineralizing solution 'in situ' at a ratio of $1: 1(\mathrm{v} / \mathrm{v})$ and prior to being in contact with the specimens with the aim to simulate acid clearance from the oral cavity through the action of saliva. The demineralization challenge was then injected at a flow rate of only 0.1 $\mathrm{ml} / \mathrm{min}$ to prevent erosion of the specimens. Pump speeds that simulate typical salivary flow rates were used for the remineralizing solution and
Table 1. Daily $\mathrm{pH}$ cycling regimen.

\begin{tabular}{|c|c|c|}
\hline Step & Procedure & Treatment \\
\hline 1 & Treatment & Deionized water or 383 ppm F (1 min) \\
\hline 2 & Demineralization & $\begin{array}{l}\text { Demineralization challenge }(30 \mathrm{~min}) \\
\text { Demineralization challenge mixed with remineralizing } \\
\text { solution }(30 \mathrm{~min})^{*} \\
\text { Remineralizing solution }(10 \mathrm{~min})\end{array}$ \\
\hline 3 & Demineralization & $\begin{array}{l}\text { Demineralization challenge }(30 \mathrm{~min}) \\
\text { Demineralization challenge mixed with remineralizing } \\
\text { solution }(30 \mathrm{~min}) \\
\text { Remineralizing solution }(10 \mathrm{~min})\end{array}$ \\
\hline 4 & Demineralization & $\begin{array}{l}\text { Demineralization challenge }(30 \mathrm{~min}) \\
\text { Demineralization challenge mixed with remineralizing } \\
\text { solution }(30 \mathrm{~min}) \\
\text { Remineralizing solution }(10 \mathrm{~min})\end{array}$ \\
\hline 5 & Demineralization & $\begin{array}{l}\text { Demineralization challenge }(30 \mathrm{~min}) \\
\text { Demineralization challenge mixed with remineralizing } \\
\text { solution }(30 \mathrm{~min}) \\
\text { Remineralizing solution }(10 \mathrm{~min})\end{array}$ \\
\hline 6 & Demineralization & $\begin{array}{l}\text { Demineralization challenge }(30 \mathrm{~min}) \\
\text { Demineralization challenge mixed with remineralizing } \\
\text { solution }(30 \mathrm{~min}) \\
\text { Remineralizing solution }(10 \mathrm{~min})\end{array}$ \\
\hline 7 & Treatment & Deionized water or 383 ppm F (1 min) \\
\hline 8 & Remineralization & Remineralizing solution $(10 \mathrm{~min})$ \\
\hline 9 & Remineralization & Remineralizing solution (static, overnight) \\
\hline
\end{tabular}

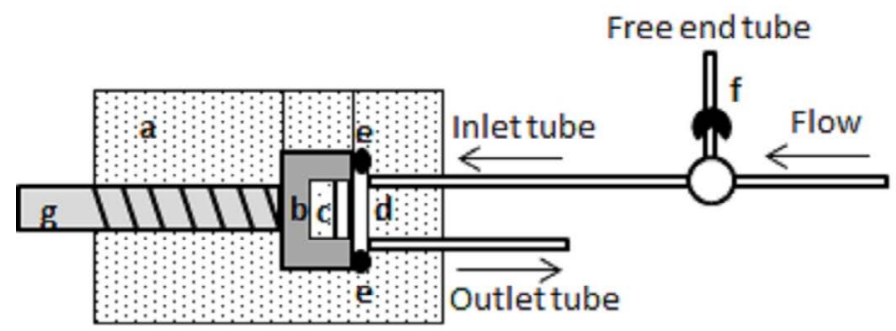

Figure 1. Schematic drawing of the continuous flow chamber (a). The block (b) containing the embedded enamel specimen with the agarose gel facing the chamber (c) is positioned into the acrylic device (d), which is sealed with a rubber O-ring (e). Fluid is flowing towards the chamber and the free end tube, used for fluoride treatments, is closed using a switch valve (f). A screw was used to hold the block in position (g).

set to either 0.05 ('dry mouth') or $0.5 \mathrm{ml} / \mathrm{min}$ ('normal'). After the last cycle each day, specimens remained in their chamber with the pumps being switched off until the next test day. Specimens were exposed to treatments by means of the free-end tube. The tube connected to the pump was closed and $20 \mathrm{ml}$ of each solution injected into the tube for $1 \mathrm{~min}$ each, twice daily. Then, the chambers were rinsed with 20 $\mathrm{ml}$ deionized water before $\mathrm{pH}$ cycling continued. The experiment was conducted at room temperature.

\section{Statistical analysis}

Three-way ANOVA was used to compare the effects of gel thickness, remineralizing solution flow rate, and fluoride concentration on $\triangle$ VHN. Pair-wise comparisons between treatment combinations were made using Fisher's Protected Least Significant Differences to control the overall significance level at $5 \%$. Statistical analyses were performed using the Statistical Package for Social Sciences (SPSS, v. 20.0, Armonk, NY, USA).

\section{Results}

Figure 2 shows the $\triangle \mathrm{VHN}$ for all treatment groups. The three-way interaction among gel thickness, remineralizing solution flow rate, and fluoride concentration was significant $(\mathrm{P}=0.0006)$. 


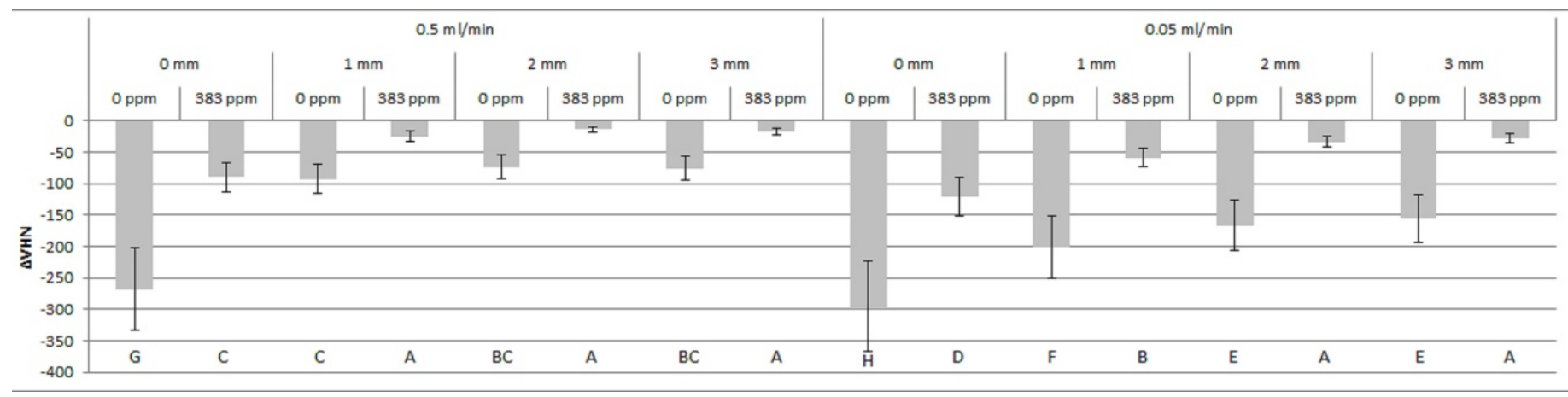

Figure 2. Change in mean Vickers surface microhardness $(\Delta \mathrm{VHN})$ for all treatment groups. X-axis labels: remineralization solution flow rate (top), gel thickness (middle), fluoride concentration (bottom). Error bars denote standard deviations. Different letters indicate statistically significant differences between treatment groups.

Fluoride concentration effect: $0 \mathrm{ppm} F$ caused more softening than $383 \mathrm{ppm} F(\mathrm{P}<0.0001)$ and irrespective of gel thickness or remineralizing solution flow rate.

Remineralizing solution flow rate effect: Flow rate of $0.5 \mathrm{ml} / \mathrm{min}$ was more protective against demineralization than $0.05 \mathrm{ml} / \mathrm{min}$ for $0 \mathrm{~mm}$ artificial biofilm thickness $(\mathrm{P}=0.0002)$ regardless of fluoride concentration, for $1 \mathrm{~mm}$ thickness $(\mathrm{P}<0.0001)$ regardless of fluoride concentration (although the effect size was smaller due to flow rate effect for 383ppm vs. 0 ppm F), for $2 \mathrm{~mm}$ thickness with 0 ppm F $(\mathrm{P}<$ $0.0001)$, and for $3 \mathrm{~mm}$ thickness with $0 \mathrm{ppm} \mathrm{F}(\mathrm{P}<0.0001)$. There was no significant effect of flow rate for $383 \mathrm{ppm} F$ with thickness of $2 \mathrm{~mm}$ $(\mathrm{P}=0.07)$ or $3 \mathrm{~mm}(\mathrm{P}=0.31)$.

Artificial biofilm thickness effect: For $0.05 \mathrm{ml} / \mathrm{min}$ flow rate, surface softening was reduced as gel thickness increased from 0 to 1 to $2 \mathrm{~mm}$ $(\mathrm{P} \leq 0.001)$; however, the difference from 2 to $3 \mathrm{~mm}$ was not significant $(\mathrm{P}=0.54)$. For $0.5 \mathrm{ml} / \mathrm{min}$ flow rate, the absence of artificial biofilm $(0$ $\mathrm{mm}$ ) resulted in more demineralization than $1 ; 2$ and $3 \mathrm{~mm}$ thicknesses $(\mathrm{P}<0.0001)$, although $1 ; 2$ and $3 \mathrm{~mm}$ thicknesses were not different from each other for 0 ppm $\mathrm{F}$ ( $\mathrm{P}=0.08$ for $1 \mathrm{vs} .2 \mathrm{~mm}, \mathrm{P}=0.11$ for $1 \mathrm{vs}$. $3 \mathrm{~mm}, \mathrm{P}=0.85$ for 2 vs. $3 \mathrm{~mm}$ ) or $383 \mathrm{ppm} \mathrm{F}(\mathrm{P}=0.27$ for 1 vs. $2 \mathrm{~mm}$, $\mathrm{P}=0.47$ for 1 vs. $3 \mathrm{~mm}, \mathrm{P}=0.70$ for 2 vs. $3 \mathrm{~mm}$ ).

\section{Discussion}

The effect of biofilm thickness on caries development has attracted some interest in the past, although results were equivocal. While some in situ studies highlighted greater demineralization with increased biofilm thickness [20,21], another did not for a glucan biofilm and even showed opposite effects for a non-glucan biofilm [22]. Using a mathematical model, the effect of biofilm thickness was shown to be modulated by sucrose concentration and duration [23]; i.e. an "optimum thickness" of biofilm exists for various sucrose exposures. Furthermore, biofilm varies in its biochemical composition and structurally at various sites in the oral cavity [24] - variables which have been shown to correlate with caries increment [25], adding another layer of complexity. The present findings would suggest that, for normal salivary flow, biofilm thickness is somewhat irrelevant, providing the biofilm is actually present. Under compromised salivary flow conditions, however, artificial biofilm thickness did affect the extent of lesion formation (Figure 2). In this context, it is worth pointing out fundamental differences between in vivo biofilms and the present model system. Firstly, in in vivo biofilms, acid is produced through fermentation of carbohydrates; sucrose, for example, diffuses into the biofilm and bacteria in the biofilm produce organic acids. Depending on the ability of carbohydrates to diffuse into the biofilm, acids could be produced close to the saliva-biofilm, at the biofilm-tooth interfaces, or at intermediate biofilm depths. Hence, the highest demineralizing potential may not necessarily be found at the deepest part within a biofilm such as in occlusal caries, where demineralization is often initiated along the entrance of the fissures rather than at the deepest part [26]. In the present study, acid was not produced within the artificial biofilm but had to diffuse through it to reach the enamel surface. The effects of acid, calcium, phosphate, and fluoride were determined by their ability to diffuse through the artificial biofilm and be retained in it. Consequently, the sequence of treatments and their duration allows for virtually complete control of experimental conditions which should prove useful in future studies of mechanistic nature on, for example, concentration gradients of actives in biofilms. Secondly, biofilms vary in porosity as the availability of nutrients, and in particular sucrose, determines the structural backbone through the synthesis of extracellular polysaccharides (glucan) which in turn promote the accumulation of S. mutans, limit diffusion of substances into and out of the biofilm and thereby determine biofilm cariogenicity [27,28]. Gels prepared at higher agarose concentrations could potentially be utilized to mimic diffusion-limiting aspects of biofilms.

The findings for remineralizing solution flow rate were expected and mirrored clinical observations [29]. Compromised salivary flow has a negative impact on the clearance of carbohydrates, or in the present study, clearance of acid from the artificial biofilm through both raising the degree of saturation and rinsing away of acids. However, this also applies to the delivered fluoride, which under low flow conditions would be more substantive. Dry mouth subjects exhibit significantly better fluoride retention than those with normal salivary flow $[30,31]$. In the present model system, the effect size of fluoride (i.e. numerical difference to placebo) was more pronounced for the $0.05 \mathrm{ml} / \mathrm{min}$ flow. Although fluoride did not fully compensate for remineralizing solution flow deficiencies, fluoride was able to minimize the effect, and perhaps higher concentrations, such as those recommended for high-risk populations, would have been able to reduce lesion formation even further. Changes in the subjects' saliva composition [32], diet and microflora [33] have been observed, all leading to an increase in caries risk beyond that already resulting from compromised salivary flow alone. These aspects would need to be taken into account in future studies, by modifying both acid challenges and remineralizing solution composition.

In conclusion, the present findings suggest that the efficacy of fluoride in preventing enamel demineralization is affected by both biofilm thickness and artificial saliva flow rate.

\section{Conflicts of interest statement}

This study was supported by GlaxoSmithKline, UK. 


\section{Acknowledgments}

This study was supported by GlaxoSmithKline, UK. The authors thank Mr. G.J. Eckert for the statistical analysis of the data.

\section{References}

1. White DJ (1995) The application of in vitro models to research on demineralization and remineralization of the teeth. Adv Dent Res 9: 175-193. [Crossref]

2. Zero DT (1995) In situ caries models. Adv Dent Res 9: 214-230. [Crossref]

3. Lippert F, Butler A, Lynch RJ, Hara AT (2012) Effect of fluoride, lesion baseline severity and mineral distribution on lesion progression. Caries Res 46: 23-30. [Crossref]

4. ten Cate JM (1999) Current concepts on the theories of the mechanism of action of fluoride. Acta Odontol Scand 57: 325-329. [Crossref]

5. Watson PS, Pontefract HA, Devine DA, Shore RC, Nattress BR, et al. (2005) Penetration of fluoride into natural plaque biofilms. J Dent Res 84: 451-455. [Crossref]

6. Fontana M, Dunipace AJ, Gregory RL, Noblitt TW, Li Y, et al. (1996) An in vitro microbial model for studying secondary caries formation. Caries Res 30: 112-128. [Crossref]

7. van Strijp AJ, van Steenbergen TJ, ten Cate JM (1997) Effects of chlorhexidine on the bacterial colonization and degradation of dentin and completely demineralized dentin in situ. Eur J Oral Sci 105: 27-35. [Crossref]

8. Giertsen E, Guggenheim B, Thurnheer T, Gmür R (2000) Microbiological aspects of an in situ model to study effects of antimicrobial agents on dental plaque ecology. Eur J Oral Sci 108: 403-411. [Crossref]

9. Robinson C, Kirkham J, Percival R, Shore RC, Bonass WA, et al. (1997) A method for the quantitative site-specific study of the biochemistry within dental plaque biofilms formed in vivo. Caries Res 31: 194-200. [Crossref]

10. McBain AJ (2009) Chapter 4: In vitro biofilm models: an overview. Adv Appl Microbiol 69: 99-132. [Crossref]

11. Lecomte P, Dawes C (1987) The influence of salivary flow rate on diffusion of potassium chloride from artificial plaque at different sites in the mouth. $J$ Dent Res 66 : 1614-1618. [Crossref]

12. Blake-Haskins JC, Mellberg JR, Snyder C (1992) Effect of calcium in model plaque on the anticaries activity of fluoride in vitro. J Dent Res 71: 1482-1486. [Crossref]

13. Whitford GM, Wasdin JL, Schafer TE, Adair SM (2002) Plaque fluoride concentrations are dependent on plaque calcium concentrations. Caries Res 36: 256-265. [Crossref]

14. ten Cate JM (1997) Review on fluoride, with special emphasis on calcium fluoride mechanisms in caries prevention. Eur J Oral Sci 105: 461-465. [Crossref]

15. Fontana M, Gonzalez-Cabezas C (2012) Minimal intervention dentistry: part 2. Caries risk assessment in adults. Br Dent J 213: 447-451. [Crossref]

16. Rowles SL, Sidaway DA, Macgregor AB, Marsland EA (1963) An apparatus for the production of dental caries in vitro. Arch Oral Biol 8: 311-318. [Crossref]
17. Scaramucci T, Borges AB, Lippert F, Frank NE, Hara AT (2013) Sodium fluoride effect on erosion-abrasion under hyposalivatory simulating conditions. Arch Oral Biol 58: 1457-1463. [Crossref]

18. Borges AB, Scaramucci T, Lippert F, Zero DT, Hara AT (2014) Erosion protection by calcium lactate/sodium fluoride rinses under different salivary flows in vitro. Caries Res 48: 193-199. [Crossref]

19. Scaramucci T, Borges AB, Lippert F, Zero DT, Hara AT (2015) In vitro effect of calcium-containing prescription-strength fluoride toothpastes on bovine enamel erosion under hyposalivation-simulating conditions. Am J Dent 28: 18-22. [Crossref]

20. Dijkman AG, Schuthof J, Arends J (1986) In vivo remineralization of plaque-induced initial enamel lesions--a microradiographic investigation. Caries Res 20: 202-208. [Crossref]

21. Mellberg JR, Petrou ID, Grote NE (1990) The effect of plaque thickness on progression of artificial caries lesion formation in situ. J Dent Res 69: 865-867. [Crossref]

22. Zero DT, Campbell JL, Yang Z (1988) Intraoral effect of plaque thickness and packing density on enamel demineralization. Caries Res 22: 96.

23. Dawes C, Dibdin GH (1986) A theoretical analysis of the effects of plaque thickness and initial salivary sucrose concentration on diffusion of sucrose into dental plaque and its conversion to acid during salivary clearance. J Dent Res 65: 89-94. [Crossref]

24. Wilson RF, Ashley FP (1988) Collection and biochemical analysis of human dental plaque from the approximal tooth surfaces and comparison with plaque from free smooth surfaces. Arch Oral Biol 33: 473-478. [Crossref]

25. Wilson RF, Ashley FP (1990) The relationship between the biochemical composition of dental plaque from both approximal and free smooth surfaces of teeth and subsequent 3-year caries increment in adolescents. Arch Oral Biol 35: 933-937. [Crossref]

26. Fejerskov O, Nyvad B, Kidd EAD (2008) Pathology of dental caries. In: Fejerskov O, Kidd EAD, eds. Dental Caries - The Disease and its Management, 2nd ed. Oxford: Blackwell Munksgaard, 19-48.

27. Zero DT, van Houte J, Russo J (1986) The intra-oral effect on enamel demineralization of extracellular matrix material synthesized from sucrose by Streptococcus mutans. $J$ Dent Res 65: 918-923. [Crossref]

28. Flemming HC1, Wingender J (2010) The biofilm matrix. Nat Rev Microbiol 8: 623633. [Crossref]

29. Atkinson JC, Wu AJ (1994) Salivary gland dysfunction: causes, symptoms, treatment J Am Dent Assoc 125: 409-416. [Crossref]

30. Sjögren K, Birkhed D, Persson LG, Norén JG (1993) Salivary fluoride clearance after a single intake of fluoride tablets and chewing gums in children, adults, and dry mouth patients. Scand J Dent Res 101: 274-278. [Crossref]

31. Billings RJ, Meyerowitz C, Featherstone JD, Espeland MA, Fu J, et al. (1988) Retention of topical fluoride in the mouths of xerostomic subjects. Caries Res 22: 306310. [Crossref]

32. Nederfors T1 (2000) Xerostomia and hyposalivation. Adv Dent Res 14: 48-56. [Crossref]

33. Brown LR, Dreizen S, Handler S, Johnston DA (1975) Effect of radiation-induced xerostomia on human oral microflora. $J$ Dent Res 54: 740-750. [Crossref]

Copyright: $\odot 2017$ Lippert F. This is an open-access article distributed under the terms of the Creative Commons Attribution License, which permits unrestricted use, distribution, and reproduction in any medium, provided the original author and source are credited. 